\title{
Identification of volatile compounds from bacteria by spectrometric methods in medicine diagnostic and other areas: current state and perspectives
}

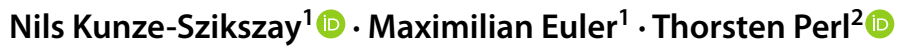

Received: 8 May 2021 / Revised: 20 July 2021 / Accepted: 22 July 2021 / Published online: 20 August 2021

(c) The Author(s) 2021, corrected publication 2021

\begin{abstract}
Diagnosis of bacterial infections until today mostly relies on conventional microbiological methods. The resulting long turnaround times can lead to delayed initiation of adequate antibiotic therapy and prolonged periods of empiric antibiotic therapy (e.g., in intensive care medicine). Therewith, they contribute to the mortality of bacterial infections and the induction of multidrug resistances. The detection of species specific volatile organic compounds (VOCs) emitted by bacteria has been proposed as a possible diagnostic approach with the potential to serve as an innovative point-of-care diagnostic tool with very short turnaround times. A range of spectrometric methods are available which allow the detection and quantification of bacterial VOCs down to a range of part per trillion. This narrative review introduces the application of spectrometric analytical methods for the purpose of detecting VOCs of bacterial origin and their clinical use for diagnosing different infectious conditions over the last decade.
\end{abstract}

\section{Key Points}

- Detection of VOCs enables bacterial differentiation in various medical conditions.

- Spectrometric methods may function as point-of-care diagnostics in near future.

Keywords Bacteria $\cdot$ Volatile organic compounds $\cdot$ Spectrometry $\cdot$ Breath analyses $\cdot$ Diagnostics $\cdot$ Mass spectrometry $\cdot$ Ion mobility spectrometry

\section{Introduction}

In 1921, 100 years before this manuscript was put together, Harper F. Zoller and W. Mansfield Clark published a bench study on the production of volatile fatty acids by dysenteric bacteria and the influence of different growing conditions on their production (Zoller and Clark 1921). By the use of distillation, they directly verified the types and amounts of fatty acids produced by several bacterial strains and concluded that those might significantly contribute to the "unpleasant symptoms" which correlated with bacterial infections of the human intestinal tract. Most likely, neither of them was thinking about the possibility of

Nils Kunze-Szikszay

nkunze@gwdg.de

1 Department of Anesthesiology, University Medical Center Göttingen, Robert-Koch-Straße 40, 37075 Göttingen, Germany

2 Department of General, Visceral and Pediatric Surgery, University Medical Center Göttingen, Robert-Koch-Straße 40, 37075 Göttingen, Germany detecting volatile organic compounds (VOCs) as an option for the diagnosis of infectious diseases. Nowadays, with analytical methods allowing the detection of lowest quantities of VOCs in a headspace or exhaled breath sample, non-invasive diagnostic tools based on gas analytics seem to be within reach.

Bacterial infections and the rise of multidrug resistances significantly contribute to morbidity and mortality worldwide. Mortality rates in septic shock, for which bacterial infections are the leading cause, do rise above $50 \%$, even if patients are treated in a modern intensive care unit (SepNet Critical Care Trials Group 2016). Early diagnosis and pathogen identification are crucial for the treatment of bacterial infections. The early beginning and the adequacy of the initial antibiotic therapy significantly contribute to the patient's outcome (Kumar et al. 2009). However, no biomarkers are available that reliably predict the onset of bacterial infections or sepsis. Diagnosis therefore remains clinical and needs to rely on potentially life-threatening symptoms of the patients (Singer et al. 2016). Until today, culturing is the standard method for the identification of causative pathogens 
Table 1 List of studies discussed in this review that include clinical application of analytical methods

\begin{tabular}{|c|c|c|c|c|c|c|c|}
\hline Study & Year & Sample size & Setting & $\begin{array}{l}\text { Conditions and } \\
\text { pathogens studied }\end{array}$ & $\begin{array}{l}\text { Analytical } \\
\text { method }\end{array}$ & Sample matrix & Sample method \\
\hline \multicolumn{8}{|c|}{ Respiratory infections } \\
\hline Nasir et al & 2018 & 60 & Single-center, UK & $\begin{array}{l}\text { Cystic fibrosis }(P . \\
\text { aeruginosa, } S . \\
\text { aureus) }\end{array}$ & GCxGC-TOF-MS & $\mathrm{BAL}^{1}$ & Direct analysis \\
\hline $\begin{array}{l}\text { Coronel Teixeira } \\
\text { et al }\end{array}$ & 2017 & 106 & $\begin{array}{l}\text { Single-center, } \\
\text { Paraguay }\end{array}$ & $\begin{array}{l}\text { Tuberculosis }(M . \\
\text { tuberculosis) }\end{array}$ & e-nose & Breath & Direct analysis \\
\hline Zetola et al & 2017 & 71 & $\begin{array}{l}\text { Single-center, } \\
\text { Botswana }\end{array}$ & $\begin{array}{l}\text { Tuberculosis }(M . \\
\text { tuberculosis) }\end{array}$ & e-nose & Breath & $\begin{array}{l}\text { Pre-collected, } \\
\text { sampling bags }\end{array}$ \\
\hline Van Oort et al & 2017 & 93 & $\begin{array}{r}\text { Single-center, } \\
\text { Netherlands }\end{array}$ & VAP $^{2}$ & GC-MS & Breath & $\begin{array}{l}\text { Pre-collected, } \\
\text { sampling bags }\end{array}$ \\
\hline Gao et al & 2016 & 60 & $\begin{array}{l}\text { Single-center, PR } \\
\text { China }\end{array}$ & $\begin{array}{l}\operatorname{VAP}^{2} \text { (A. bauma- } \\
\text { nii) }\end{array}$ & GC-MS & Breath & $\begin{array}{l}\text { Pre-collected, des- } \\
\text { orption tubes }\end{array}$ \\
\hline Neerincx et al & 2016 & 18 & $\begin{array}{r}\text { Single-center, } \\
\text { Netherlands }\end{array}$ & $\begin{array}{l}\text { Cystic fibrosis ( } S \text {. } \\
\text { aureus) }\end{array}$ & GC-MS & Breath & $\begin{array}{l}\text { Pre-collected, } \\
\text { sampling bags }\end{array}$ \\
\hline Sahota et al & 2016 & 21 & Single-center, UK & $\begin{array}{l}\text { Tuberculosis }(M . \\
\text { tuberculosis) }\end{array}$ & FAIMS & Breath & $\begin{array}{l}\text { Pre-collected, } \\
\text { sampling bags }\end{array}$ \\
\hline Fowler et al & 2015 & 46 & Single-center, UK & $\begin{array}{l}\text { Lower airway infec- } \\
\text { tions }\end{array}$ & GC-MS & Breath & $\begin{array}{l}\text { Pre-collected, des- } \\
\text { orption tubes }\end{array}$ \\
\hline Kramer et al & 2015 & 11 & $\begin{array}{l}\text { Single-center, } \\
\text { Germany }\end{array}$ & $\begin{array}{l}\text { Cystic fibrosis } \\
\text { (P. aeruginosa, } \\
\text { S. aureus, } C . \\
\text { albicans, } A . \\
\text { xylososidans })\end{array}$ & GC-MS & Breath & SPME \\
\hline Schnabel et al & 2015 & 100 & $\begin{array}{r}\text { Single-center, } \\
\text { Netherlands }\end{array}$ & $\mathrm{VAP}^{2}$ & GC-TOF-MS & Breath & $\begin{array}{l}\text { Pre-collected, } \\
\text { sampling bags }\end{array}$ \\
\hline Filipiak et al & 2014 & 28 & $\begin{array}{l}\text { Single-center, } \\
\text { Austria }\end{array}$ & $\begin{array}{l}\operatorname{VAP}^{2}(S . \text { aureus }, C . \\
\quad \text { albicans, } \text { E. coli })\end{array}$ & GC-TOF-MS & Breath & $\begin{array}{l}\text { Pre-collected, des- } \\
\text { orption tubes }\end{array}$ \\
\hline Nakhleh et al & 2014 & 198 & $\begin{array}{l}\text { Multi-center, Rep. } \\
\text { of South Africa }\end{array}$ & $\begin{array}{l}\text { Tuberculosis }(M . \\
\text { tuberculosis })\end{array}$ & e-nose & Breath & $\begin{array}{l}\text { Pre-collected, des- } \\
\text { orption tubes }\end{array}$ \\
\hline Gilchrist et al & 2013 & 20 & Single-center, UK & $\begin{array}{l}\text { Cystic fibrosis ( } P \text {. } \\
\text { aeruginosa, } S . \\
\text { aureus) }\end{array}$ & SIFT-MS & Breath & Direct analysis \\
\hline Goeminne et al & 2012 & 28 & $\begin{array}{l}\text { Single-center, } \\
\text { Belgium }\end{array}$ & $\begin{array}{c}\text { Cystic fibrosis }(P . \\
\text { aeruginosa) }\end{array}$ & GC-MS & Sputum & SPME \\
\hline \multicolumn{8}{|c|}{ Gastrointestinal infections } \\
\hline Berkhout et al & 2019 & 843 & $\begin{array}{l}\text { Multi-center, Neth- } \\
\text { erlands/Belgium }\end{array}$ & $\begin{array}{l}\text { Neonatal late-onset } \\
\text { sepsis }\end{array}$ & FAIMS & Stool & $\begin{array}{l}\text { Direct headspace } \\
\text { sampling }\end{array}$ \\
\hline Patel et al & 2019 & 106 & Single-center, UK & $\mathrm{CDI}^{4}$ (C. difficile) & GC-TOF-MS & Stool & $\begin{array}{l}\text { Pre-collected head- } \\
\text { space, desorption } \\
\text { tubes }\end{array}$ \\
\hline Arasaradnam et al & 2016 & 76 & Single-center, UK & $\mathrm{IBD}^{3}$ & FAIMS & Breath & $\begin{array}{l}\text { Pre-collected, } \\
\text { sampling bags }\end{array}$ \\
\hline Bromers et al & 2015 & 213 & $\begin{array}{l}\text { Two-center, Nether- } \\
\text { lands }\end{array}$ & $\mathrm{CDI}^{4}(C$. difficile $)$ & FAIMS & Stool & $\begin{array}{l}\text { Direct headspace } \\
\text { sampling }\end{array}$ \\
\hline Arasaradnam et al & 2013 & 62 & Single-center, UK & $\mathrm{IBD}^{3}$ & e-nose, FAIMS & Urine & $\begin{array}{l}\text { Direct headspace } \\
\text { sampling }\end{array}$ \\
\hline Garner et al & 2009 & 9 & $\begin{array}{c}\text { Single-center, } \\
\text { Bangladesh }\end{array}$ & $\begin{array}{l}\text { Cholera (V. chol- } \\
\text { era) }\end{array}$ & GC-MS & Stool & SPME \\
\hline Lechner et al & 2005 & 25 & $\begin{array}{l}\text { Single-center, } \\
\text { Austria }\end{array}$ & Gastritis (H. pylori) & PTR-MS & Breath & $\begin{array}{l}\text { Pre-Collected, } \\
\text { Sampling bags }\end{array}$ \\
\hline \multicolumn{8}{|c|}{ Bloodstream infections } \\
\hline Zhong et al & 2019 & 46 & $\begin{array}{l}\text { Single-center, PR } \\
\text { China }\end{array}$ & $\operatorname{BSI}^{5}$ (E. coli) & CDI-MS & Blood & SPME \\
\hline
\end{tabular}


Table 1 (continued)

\begin{tabular}{|c|c|c|c|c|c|c|c|}
\hline Study & Year & Sample size & Setting & $\begin{array}{l}\text { Conditions and } \\
\text { pathogens studied }\end{array}$ & $\begin{array}{l}\text { Analytical } \\
\text { method }\end{array}$ & Sample matrix & Sample method \\
\hline Chingin et al & 2015 & 130 & $\begin{array}{l}\text { Single-center, PR } \\
\text { China }\end{array}$ & $\begin{array}{l}\operatorname{BSI}^{5}(S . \text { aureus, } E . \\
\text { coli, K. pneumo- } \\
\text { niae, A. baumanii, } \\
\text { P. aeruginosa })\end{array}$ & APCI-MS & Blood & $\begin{array}{l}\text { Direct headspace } \\
\text { sampling }\end{array}$ \\
\hline \multicolumn{8}{|l|}{ Other infections } \\
\hline Daulton et al & 2020 & 19 & Single-center, UK & Wound infection & GC-IMS & Wound dressing & $\begin{array}{l}\text { Direct headspace } \\
\text { sampling }\end{array}$ \\
\hline Lacey et al & 2020 & 243 & Single-center, UK & $\begin{array}{l}\text { Maternal strepto- } \\
\text { coccal coloniza- } \\
\text { tion (group B } \\
\text { streptococci) }\end{array}$ & GC-IMS & Vaginal swabs & $\begin{array}{l}\text { Direct headspace } \\
\text { sampling }\end{array}$ \\
\hline Kviatkovski et al & 2018 & 26 & Single-center, Israel & $\begin{array}{c}\text { Otitis externa }(P . \\
\text { aeruginosa) }\end{array}$ & GC-MS & Pus samples & $\begin{array}{l}\text { Pre-collected, des- } \\
\text { orption tubes }\end{array}$ \\
\hline Blankenstein et al & 2015 & 57 & $\begin{array}{l}\text { Single-center, } \\
\text { Germany }\end{array}$ & Bacterial vaginosis & IMS & Vaginal swabs & $\begin{array}{l}\text { Direct headspace } \\
\text { sampling }\end{array}$ \\
\hline Roine et al & 2014 & 101 & $\begin{array}{l}\text { Single-center, } \\
\text { Finland }\end{array}$ & $\begin{array}{l}\mathrm{UTI}^{6}(\text { E. coli }, S . \\
\text { saprophyticus, } \\
\text { E. faecalis, Kleb- } \\
\text { siella } \text { spp. })\end{array}$ & e-nose & Urine & $\begin{array}{l}\text { Direct headspace } \\
\text { sampling }\end{array}$ \\
\hline Chaim et al & 2003 & 174 & Single-center, Israel & Bacterial vaginosis & IMS & Vaginal swabs & $\begin{array}{l}\text { Direct headspace } \\
\text { sampling }\end{array}$ \\
\hline
\end{tabular}

${ }^{1} B A L$ bronchoalveolar lavage; ${ }^{2} V A P$ ventilator-associated pneumonia; ${ }^{3} I B D$ inflammatory bowel disease; ${ }^{4} C D I$ Clostridoides difficile infection; ${ }^{5} B S I$ bloodstream infection; ${ }^{6} U T I$ urinary tract infection

in medical microbiology. The use of these highly sensitive and very specific, but also time-consuming techniques, leads to turnaround times of up to 3 days for final results (Tabak et al. 2018). During this time, empiric broad-spectrum antibiotic therapy is used to treat the infection (Paul et al. 2010). Without identification of the infecting organism and its susceptibility, this empiric (or calculated) antibiotic therapy potentially risks inadequate treatment and induction of drug resistances and adverse effects (MacFadden et al. 2014).

The availability of rapid methods for the diagnosis of bacterial infections and identification of the causative pathogen would help narrowing the empiric window and therewith contribute to a safer and more effective antibiotic therapy regimen (Battle et al. 2017; Tumbarello et al. 2010). Innovative applications include microbial identification directly from positive blood cultures by the use of matrix-assisted laser desorption ionization-time-of-flight mass spectrometry (MALDI-TOF MS) or the Accelerate Pheno ${ }^{\mathrm{TM}}$ System, which combines fluorescence in situ hybridization (FISH) with morphokinetic cellular analysis (MCA) (Pancholi et al. 2018; Rodriguez-Sanchez et al. 2014). These proteomic (MALDI-TOF MS) and optical (FISH-MCA) methods contribute to shorter turnaround times and were shown to deliver reliable results on pathogen identification and antibiotic resistances. Both systems are commercially available and in clinical use. However, both methods require at least a positive blood culture (or equivalent specimen) as a starting point, which remains a limiting factor regarding turnaround times. They need to be operated by trained personnel in specialized microbiological laboratories which, together with the high costs for acquisition and operation, leads to centralization of these systems at large hospitals or commercial providers (Ratiu et al. 2017). Hospitals lacking such facilities may send their microbiological specimen to such laboratories, again increasing turnaround times is increased and in some instances risking the integrity of the specimen, depending on length and circumstances of the transport.

Multiplex polymerase chain reaction (multiplex PCR) is another innovative method allowing rapid pathogen identification including the detection of genetic antibiotic resistance markers. Currently, three systems (SepsiTest [Molzym Molecular Diagnostics, Bremen, Germany], IRIDICA BAC BSI [Abbott Diagnostics, Lake Forest, USA], LightCycler SeptiFast [Roche, Risch-Rotkreuz, Switzerland]) are commercially available for pathogen identification from blood cultures (Stevenson et al. 2016). One cartridge system (Unyvero A50 [Curetis, Holzgerlingen, Germany]) is targeting several localized infection sides as well as bloodstream infections (Burrack-Lange et al. 2018). Of those, the Unyvero A50 is the only system that can be operated pointof-care, which leads to relevant reduction of turnaround times (Kunze et al. 2015). However, multiplex PCR devices are not part of the clinical routine in the majority of hospitals and possess some methodological challenges by themselves. 
Depending on the composition of the pathogen and resistance marker panel of the devices, it may, for instance, remain unclear for the user whether a detected resistance marker is associated with the detected pathogen or with a resident organism that is not part of the pathogen panel. The mecA gene is a marker for methicillin resistance and occurs in both Staphylococcus aureus and Staphylococcus epidermidis and is an example for such a possible cause of misinterpretation (Becker et al. 2006). Multiplex PCR systems incur relevant costs, and data on their ability to reduce mortality, morbidity, and therapy costs remain inconsistent (Warhurst et al. 2015). Their use will therefore be limited to highly equipped hospitals in economically developed countries.

The detection of VOCs of microbial origin is an alternative approach with the potential to be a robust, fast, and relatively low-cost point-of-care method for pathogen differentiation and identification. A variety of analytical methods allows the detection and identification of VOCs (Ratiu et al. 2017). There is growing knowledge on the occurrence and composition of volatile metabolites emitted from bacteria and other microbes (Bos et al. 2013; Schulz and Dickschat 2007). With this narrative review, we aim to give a brief overview on the current state of knowledge on the use of spectrometric methods for the diagnosis of bacterial infections and possible perspective of their future use.

\section{Spectrometric methods for VOC detection}

The metabolic pathways of bacteria have been investigated in detail (Schulz and Dickschat 2007). Ideally, the occurrence of a VOC should be assignable to a known metabolic pathway. However, the production of VOCs by bacteria is influenced by their growing conditions (O'Hara and Mayhew 2009). Our knowledge of bacterial metabolic pathways and therewith VOC production under various conditions in the human body is still very limited. In 2013, Bos et al. published a detailed review of VOCs produced by the six most relevant bacteria in sepsis: $S$. aureus, $S$. pneumoniae, E. faecalis, $K$. pneumoniae, $P$. aeruginosa, and $E$. coli (Bos et al. 2013).

The analytical challenge for available devices is the detection and quantification of VOCs in a complex matrix of gaseous samples with traces down to parts per billion (ppb) or even trillion (ppt). Ideally, the detected VOCs are produced by species cultivated on defined, standardized substrate such as culture media. In the clinical context, it may also be desirable to directly detect VOCs from highly diverse substrates like urine, feces, sputum, vaginal fluids, tissues, or breath (Amann et al. 2014; Eng et al. 2015; Lacey et al. 2020; Purkhart et al. 2011; Ratiu et al. 2019).

Gas chromatography coupled with mass spectrometry (GC-MS) is the gold standard for VOC detection (Ratiu et al. 2017). GC-MS does possess large databases for identification of substances and the capability of separating and unequivocal identification of compounds. Multiple publications in the field of bacterial VOC determination with GC-MS demonstrated its applicability for this purpose (Liebeke et al. 2012; Tait et al. 2014). Alternatives to $\mathrm{GC}-\mathrm{MS}$ are other mass spectrometric instrumentations like proton transfer reaction-mass spectrometers (PTRMS) or selected ion flow tube-mass spectrometer (SIFTMS). Secondary electrospray ionization mass spectrometry (SESI-MS) has been shown to be more sensitive compared to PTR-MS or SIFT-MS enabling substance detection in the ppt range (Woolfenden 2010). A strength of these devices, which are still bulky and not portable, is the possibility of real-time measurements at a high sensitivity in range of ppb. However, a chemical identification of unknown VOCs is not possible.

Immobility due to bulky setup and need for high effective vacuum pumps and purified gas supply is a common drawback of all mass spectrometric devices. Thus, gas samples for diagnostic purposes need be transferred to the device for offline analysis. Gas bags or absorptive mediums like needle traps and solid-phase microextraction tools are used to transfer the sample to the mass spectrometric device. These pre-concentration techniques possibly influence compound composition of gas samples by selective absorption and desorption depending on characteristics of the chosen transfer material (Slingers et al. 2021). Therefore, a favorable approach to determine VOCs is not only to measure real-time but also in a point-of-care setting with the possibility of direct sampling at the patient's bed side (e.g., breath sampling).

In contrast to mass spectrometric methods, ion mobility spectrometry (IMS) applications are portable and even available as handhelds. IMS devices are already widely used by rescue services, security authorities, and the military for the detection of hazardous substances, explosives, and chemical warfare agents (Cumeras et al. 2015). The method allows substance detection and quantification down to a range of ppt (Kunze et al. 2015). Time-of-flight-IMS (TOF-IMS), aspiration-IMS (aIMS), field asymmetric ion mobility spectrometry (FAIMS), and differential mobility spectrometers IMS (DMS) have been described for microbiological VOC detection (Costanzo et al. 2017; Ratiu et al. 2017). IMS devices can be used separately (e.g., as screening tools for a known substance), or they can be coupled with a chromatographic method, which allows analyses of more complex gas samples. GC columns or multicapillary columns (MCC) are mostly used for preseparating complex matrices such as breath or headspace samples of complex growth media (Baumbach 2009; Speckbacher et al. 2021). IMS devices are inexpensive, robust, and portable. They therefore have the potential 
to serve as point-of-care diagnostic tools in challenging healthcare settings.

The spectrum of IMS-based analytical methods is growing. Couplings of more than one detector (e.g., FAIMSFAIMS), the use of different pre-separation methods (e.g., GC, MCC), different ionization methods, and even pre-concentration techniques facilitate individual analytical solutions for specific circumstances. However, due to diverse setup of these systems, a comparison of findings is difficult. Targeted analyses are possible when known substances are investigated, and reference measurements can be provided for confirmation. The composition of volatile organic compounds over growing bacterial species, however, contains mostly substances that are unknown to the researcher in the first place. This untargeted analytic approach often leads to the approach of pattern recognition, where none or not all substances are identified. Using IMS techniques, the identification of (suspected) substances can be very challenging and time- and resource-consuming. The position of a substance in the topogram of a GC-IMS device is unique, but it needs to be confirmed by reference measurements of the pure substance. Once a substance is confirmed, this information can contribute to a specific database for each application, allowing identification of substances even without a reference measurement. However, this information is only valid for very similar IMS applications. The diversity of analytical setups of devices makes it often hard to compare results and to deduce conclusions from results of similar but "different enough" methods.

Electronic noses, often referred to as "e-noses", represent a third analytical approach by using biochemical sensor arrays for the detection of VOCs and VOC patterns (Wilson 2020). E-noses are small and inexpensive and allow screening for certain chemical conditions while being easy to operate. However, these devices do not allow identification of individual substances. It is therefore necessary to configure a suitable sensor array for each individual analytical question. E-nose applications may be used to translate the results of more sophisticated analytical methods, like mass spectrometric or IMS methods, into easy-to-operate and rugged bedside tools.

\section{Diagnostic applications for bacterial infections}

Over the last two decades, there is a growing interest in the experimental and clinical application of spectrometric methods for the detection of bacterial VOCs for diagnostic purposes. The results of the studies from a broad variety of medical fields underline the potential of the approach. Following, we aim to give a comprehensive overview of different applications with a focus on clinical studies published within the last 5 years (Table 1).

\section{Respiratory infections}

Tuberculosis (TB), caused by Mycobacterium tuberculosis, is one of the leading causes of death among infectious diseases worldwide (Khatua et al. 2017). A reliable, simple, and cheap test for the diagnosis of TB is of outmost interest, especially for low-income countries. In 2016, Sahota et al. described the use of a FAIMS device with a non-radioactive UV ionization source for VOC pattern recognition to diagnose TB in the UK (Sahota et al. 2016). They investigated a rather small number of 21 breath samples of TB patients compared to 19 healthy controls and found a sensitivity and specificity of $81 \%$ and $79 \%$. Three groups used e-nose devices for the same purpose and described sensitivities and specificities of $88-94 \%$ and $90-93 \%$ for diagnosing TB (Coronel Teixeira et al. 2017; Nakhleh et al. 2014; Zetola et al. 2017). None of the four studies identified individual VOCs that were used for the prediction of TB.

The majority of pulmonary infections in cystic fibrosis (CF) is caused by Pseudomonas aeruginosa (PA) or Staphylococcus aureus (SA). In 2016, Neerincx et al. published a feasibility study on the identification of SA-infected CF patients in a collective of 18 patients. Using Tedlar ${ }^{\circledR}$ bags, they collected breath samples and analyzed them using GC-MS. They were able to identify nine VOCs which were useful for separating SA-infected patients. Three of these VOCs did significantly differ between the groups (1,4 pentadiene, acetone, undecane). Interestingly, seven of the 13 CF patients infected with SA were also infected with PA, Serratia marcescens, or Haemophilus influenzae (Neerincx et al. 2016). By measuring the concentration of hydrogen cyanide using SIFT-MS analyses of nose-exhaled breath, Gilchrist et al. successfully differentiated between chronically PA-infected and non-infected CF patients (Gilchrist et al. 2013). The discrimination of PA-infected and noninfected CF patients is also possible by pattern recognition of VOCs as it was shown in a study using SPME enrichment for indirect sampling of breath for GC-MS analyses from CF patients (Kramer et al. 2015). Besides breath analysis, detection of PA-specific VOCs was also detected in sputum headspace (Goeminne et al. 2012) and over bronchoalveolar lavage fluid samples (Nasir et al. 2018).

Ventilator-associated pneumonia (VAP) is a common nosocomial infection. Diagnosis is time critical and still based on unspecific clinical criteria and pathogen detection in bronchoalveolar lavage. Breath analysis could be a feasible, non-invasive approach for both VAP diagnosis and pathogen identification. Schnabel et al. in 2015 used GCTOF-MS for investigating samples of exhaled breath from 100 ventilated patients in intensive care for the occurrence of 
VAP-specific VOCs. With a set of 12 VOCs, they were able to correctly discriminate between patients with and without VAP (Schnabel et al. 2015). Other authors described changes in the volatile metabolite profile of ventilated patients with bacterial colonization of the lower respiratory tract (Fowler et al. 2015). In 2017, van Oort et al. did also discriminate VAP from control with relatively good accuracy. They analyzed 12 VOCs that changed during pneumonia and 52 VOCs that changed in colonized patients (van Oort et al. 2017). Filipiak et al. showed that the concentration of specific compounds changed over the course of the infection and also correlated with illness severity (Filipiak et al. 2015). In 2016, Gao et al. published a study in which they differentiated the presence from the absence of $A$. baumanii in the lower respiratory tract, as well as the colonization from an actual infection using breath VOC profiles (Gao et al. 2016).

\section{Gastrointestinal infections}

Another potential application is the investigation of fecal volatilome for the diagnosis of gastrointestinal infections. One confounding factor for such analyses is the highly interindividual fecal microbiome. Together with a complex volatile background caused by fermentation processes, this leads to a challenging environment for gas analyses (Elmassry and Piechulla 2020).

Clostridioides difficile causes antibiotic associated diarrhea and has been found to cause a unique fecal volatilome. Both GC-tof-MS and FAIMS discriminated between (unprocessed) infected and uninfected stool samples with high diagnostic accuracy (Bomers et al. 2015; Patel et al. 2019). GC-MS has also been successfully used to identify volatile biomarkers of Vibrio cholorae emitted from stool samples (Garner et al. 2009).

A prospective multicenter study from the Netherlands and Belgium underlined the potential of spectrometric analytical methods for individual therapy planning. By investigating the volatilome of stool samples of 127 cases of neonatal late-onset sepsis and matched controls, they were able to discriminate both groups. They used FAIMS for analyzing unprocessed fecal samples of neonates which provides results after very short period of time (Berkhout et al. 2019).

Urea breath tests using radioactive carbon isotopes are the gold standard for diagnosing Helicobacter pylori infections and show specificity and sensitivity of approximately 95\% (Nakayama and Graham 2004). With their PTR-TOF$S$ breathing gas investigations of infected and uninfected patients, Lechner et al. found significantly elevated hydrogen cyanide and hydrogen nitrate concentrations in $H$. pyloriinfected patients (Lechner et al. 2005).

Inflammatory bowel disease diagnosis remains a clinical challenge, and Crohn's disease and ulcerative colitis have shown distinct VOCs, which seem to reflect the gut volatilome. Breath analysis differentiated inflammatory bowel disease (IBD) from control and Crohn's disease from ulcerative colitis (Arasaradnam et al. 2016). The same study groups were previously able to separate IBD patients from healthy controls by headspace analyses of urine samples using an e-nose and FAIMS, whereas both systems enabled discrimination of the groups (Arasaradnam et al. 2013).

\section{Bloodstream infections}

Bacterial bloodstream infections are a common cause for sepsis, a major burden for healthcare systems with high mortality, and require fast diagnosis and therapy (SepNet Critical Care Trials Group 2016). Diagnosis still depends on unspecific clinical presentations, and pathogen identification relies on culturing, which leads to relevant delays in initiating targeted antibiotic treatment (Singer et al. 2016).

An alternative approach could be using VOC analyses of the headspace over inoculated blood cultures. Umber et al. used different GC couplings to investigate the headspace over experimental blood cultures, consisting of LB broth, human whole blood, and E. coli. They described six VOCs that were specific for $E$. coli-infected whole blood, even when compared to samples of inoculated LB broth without blood (Umber et al. 2013). Another group used corona discharge ionization MS to describe the increase of indole in the headspace of blood cultures incubating with $E$. coli (Zhong et al. 2019). Our own group recently published promising results regarding the use of GC-IMS for rapid differentiation of E. coli, $P$. aeruginosa, and $S$. aureus by analyzing the headspace of experimental blood cultures very quickly (Drees et al. 2019).

Chingin et al. conducted the first clinical feasibility study using APCI-MS (atmospheric pressure chemical ionization mass spectrometry) to investigate the volatilome of blood cultures from patients with suspected or confirmed bacteremia. Within 3-16 h, they were able to detect specific VOC patterns and successfully differentiated between five common sepsis pathogens (Staphylococcus aureus, Escherichia coli, Klebsiella pneumoniae, Acinetobacter baumannii, and Pseudomonas aeruginosa) (Chingin et al. 2015).

\section{Other applications}

Urinary tract infections (UTI) are common and mostly caused by bacteria. In 2011, Storer et al. used SIFT-MS (selected ion flow tube mass spectrometry) to investigate the headspace over experimentally inoculated urine samples. They were able to distinguish between eight etiological bacteria and fungi, namely E. coli, $P$. vulgaris, $P$. aeruginosa, S. aureus, S. epidermidis, K. pneumoniae, E. faecalis, or C. albicans (Storer et al. 2011). In their clinical study from 2014, Roine et al. demonstrated the potential of an IMS 
based e-nose device to identify infected urine samples and to differentiate between four common causative bacteria: E. coli, S. saprophyticus, E. faecalis, and Klebsiella spp. (Roine et al. 2014).

Bacterial vaginosis is a common infection in gynecology. IMS is able to detect malodorous biogenic amines from vaginal swabs (Chaim et al. 2003). Meanwhile, IMS devices for point-of-care testing for bacterial vaginosis are commercially available and show a good accuracy (Blankenstein et al. 2015).

Infection with group B Streptococcus is a potentially lifethreatening complication in newborn infants. By analyzing maternal vaginal swabs using a GC-IMS device, Lacey et al. recently demonstrated the ability of this method to diagnose maternal group B Streptococcus infections with high sensitivity and specificity. They concluded that the use of the technique as a screening tool could significantly contribute to the prevention of the condition (Lacey et al. 2020).

Recently, Daulton et al. reported of the use of a GCIMS device to distinguish between infected and uninfected wounds. Wound infections significantly complicate the treatment of surgical patients and cause a major burden on healthcare systems worldwide. Screening for specific VOCs indicating infection of wounds could therefore be an alternative approach to the conventional microbiological diagnostic using wound swabs (Daulton et al. 2020).

By using GC-MS, Kviatkovski et al. identified 2-aminoacetophenone (2-AA) as a specific VOC indicating the presence of $P$. aeruginosa in pus samples of otitis externa patients. They assembled a device combining a whole-cell luminescent biosensor with photo-multiplier tube enabling the detection of 2-AA at very low concentrations. By using this device, they were able to diagnose otitis externa caused by $P$. aeruginosa with high accuracy (Kviatkovski et al. 2018).

\section{Future perspectives and challenges}

During the current SARS-CoV-2 pandemic, breath tests for the detection of viral infections have come in the focus of scientific and commercial interest (Ruszkiewicz et al. 2020). This demonstrates both the potential of the methodology and the challenges that come with their application. Most of the investigations cited in this review did not identify the actual substances that contribute to a VOC pattern or fingerprint that is considered to be specific for a condition. Pattern recognition leads to valuable scientific results, and it may be justifiable to relinquish substance identification as it would be time-consuming, expensive, and in some cases impossible. The development of urgently needed diagnostic tools may be hindered in an unjustifiable manner. One may however argue that identification of a substance with a clear link to a known metabolic pathway explains its occurrence in a bacterial infectious condition and therefore increases the conclusiveness of these results. During the last decade, the value of breath tests based on spectrometric methods has been investigated in a multitude of medical conditions ranging from several lung pathologies (e.g., infections, malignomas, COPD) up to neurological conditions, such as Alzheimer's disease (Bach et al. 2015; Darwiche et al. 2011; Fink et al. 2014). The limitation of the pattern recognition or fingerprinting approach without identification of volatile substances is the lack of causative explanation for its occurrence in the specific conditions. Most studies are monocentric, and the numbers of investigated patients are small, which increase the risk of random cohesions. In the best case, substance identification would make it possible to explain the origin of an occurring VOC by referencing the underlying mechanisms of, e.g., known bacterial metabolic pathways.

The sampling of human breath remains challenging, as breathing air by itself provides a high degree of diversity and complexity. Factors like gender, race, age, diet, and lifestyle habits can influence the composition of VOCs in human breath. Detection of a substance depends on its chemical and physical properties and on the ability to detect it with the chosen analytical method. For instance, may the ability of an IMS to detect indole over a growing $E$. coli culture depend on the type of GC column chosen for pre-separation. The reviewed literature demonstrates heterogeneous analytical approaches for the same or similar questions. It also shows that our knowledge on the biochemical implication of the occurrence or non-occurrence of VOCs in certain constellations remains limited and should be addressed in future research.

In the future, substance identification should be used to clearly link the results of basic research to the findings of clinical investigations. International and multicenter studies, adequately powered, are necessary to generate highquality evidence for the most urgent and promising fields of application.

As it was demonstrated by Zoller and Clark a century ago, the smell of bacteria can lead to the correct diagnosis. The ability of modern spectrometric techniques makes it possible to detect smallest amounts of volatile substances and to use gas samples as a diagnostic matrix. Growing interest of the scientific community in these methods will certainly lead to more clinical applications of point-of-care diagnostics, although challenges remain.

\section{Conclusion}

The association of volatile organic compounds (VOCs) with bacterial presence and growth has led to a novel diagnostic approach, suggesting the use of spectrometric analytical methods for the detection of pathogen-specific VOCs or 
VOC patterns. Basic research using complex, expensive, and space-consuming mass spectrometric methods provided knowledge on the occurrence of VOCs in association with several bacterial species. Based on these findings, less complex, robust, fast, and miniaturized applications, such as IMS and FAIMS, aim to transfer this knowledge into clinical, potentially point-of-care, use. Over the last two decades, a growing number of studies tested spectrometric analytical methods for diagnosing bacterial infections. As described in this review, there are more and more promising results demonstrating potential to supplement conventional microbiological methods, or even have the ability to substitute the latter in some selected conditions. However, future clinical research needs to be more standardized and adequately powered multicenter studies are needed to proof its value for human medicine.

Author contribution NKS, ME, and TP contributed to literature research and the writing of the manuscript. All authors approved the final version of the manuscript.

Funding Open Access funding enabled and organized by Projekt DEAL.

\section{Declarations}

Ethics approval This article does not contain any studies with human participants or animals performed by any of the authors.

Conflict of interest The authors declare no competing interests.

Open Access This article is licensed under a Creative Commons Attribution 4.0 International License, which permits use, sharing, adaptation, distribution and reproduction in any medium or format, as long as you give appropriate credit to the original author(s) and the source, provide a link to the Creative Commons licence, and indicate if changes were made. The images or other third party material in this article are included in the article's Creative Commons licence, unless indicated otherwise in a credit line to the material. If material is not included in the article's Creative Commons licence and your intended use is not permitted by statutory regulation or exceeds the permitted use, you will need to obtain permission directly from the copyright holder. To view a copy of this licence, visit http://creativecommons.org/licenses/by/4.0/.

\section{References}

Amann A, Costello Bde L, Miekisch W, Schubert J, Buszewski B, Pleil J, Ratcliffe N, Risby T (2014) The human volatilome: volatile organic compounds (VOCs) in exhaled breath, skin emanations, urine, feces and saliva. J Breath Res 8(3):034001. https://doi.org/ 10.1088/1752-7155/8/3/034001

Arasaradnam RP, McFarlane M, Daulton E, Skinner J, O'Connell N, Wurie S, Chambers S, Nwokolo C, Bardhan K, Savage R, Covington J (2016) Non-invasive exhaled volatile organic biomarker analysis to detect inflammatory bowel disease (IBD). Dig Liver Dis 48(2):148-153. https://doi.org/10.1016/j.dld.2015.10.013
Arasaradnam RP, Ouaret N, Thomas MG, Quraishi N, Heatherington E, Nwokolo CU, Bardhan KD, Covington JA (2013) A novel tool for noninvasive diagnosis and tracking of patients with inflammatory bowel disease. Inflamm Bowel Dis 19(5):999-1003. https://doi. org/10.1097/MIB.0b013e3182802b26

Bach JP, Gold M, Mengel D, Hattesohl A, Lubbe D, Schmid S, Tackenberg B, Rieke J, Maddula S, Baumbach JI, Nell C, Boeselt T, Michelis J, Alferink J, Heneka M, Oertel W, Jessen F, Janciauskiene S, Vogelmeier C, Dodel R, Koczulla AR (2015) Measuring compounds in exhaled air to detect Alzheimer's disease and Parkinson's disease. PLoS ONE 10(7):e0132227. https://doi.org/10. 1371/journal.pone.0132227

Battle SE, Bookstaver PB, Justo JA, Kohn J, Albrecht H, Al-Hasan MN (2017) Association between inappropriate empirical antimicrobial therapy and hospital length of stay in Gram-negative bloodstream infections: stratification by prognosis. J Antimicrob Chemother 72(1):299-304. https://doi.org/10.1093/jac/dkw402

Baumbach JI (2009) Ion mobility spectrometry coupled with multicapillary columns for metabolic profiling of human breath. J Breath Res 3(3):034001. https://doi.org/10.1088/1752-7155/3/ 3/034001

Becker K, Pagnier I, Schuhen B, Wenzelburger F, Friedrich AW, Kipp F, Peters G, von Eiff C (2006) Does nasal cocolonization by methicillin-resistant coagulase-negative staphylococci and methicillin-susceptible Staphylococcus aureus strains occur frequently enough to represent a risk of false-positive methicillin-resistant S. aureus determinations by molecular methods? J Clin Microbiol 44(1):229-31. https://doi.org/10.1128/JCM.44.1.229-231.2006

Berkhout DJC, van Keulen BJ, Niemarkt HJ, Bessem JR, de Boode WP, Cossey V, Hoogenes N, Hulzebos CV, Klaver E, Andreessen P, van Kaam AH, Kramer BW, van Lingen RA, Schouten A, van Goudoever JB, Vijlbrief DC, van Weissenbruch MM, Wicaksono AN, Covington JA, Benninga MA, de Boer NKH, de Meij TGJ (2019) Late-onset sepsis in preterm infants can be detected preclinically by fecal volatile organic compound analysis: a prospective, multicenter cohort study. Clin Infect Dis 68(1):70-77. https:// doi.org/10.1093/cid/ciy383

Bankenstein T, Lytton SD, Leidl B, Atweh E, Friese K, Mylonas I (2015) Point-of-care (POC) diagnosis of bacterial vaginosis (BV) using VGTest ${ }^{\mathrm{TM}}$ ion mobility spectrometry (IMS) in a routine ambulatory care gynecology clinic. Arch Gynecol Obstet 292(2):355-62 https://doi.org/10.1007/s00404-014-3613-x

Bomers MK, Menke FP, Savage RS, Vandenbroucke-Grauls CM, van Agtmael MA, Covington JA, Smulders YM (2015) Rapid, accurate, and on-site detection of $C$. difficile in stool samples. Am J Gastroenterol 110(4):588-94. https://doi.org/10.1038/ajg.2015.90

Bos LD, Sterk PJ, Schultz MJ (2013) Volatile metabolites of pathogens: a systematic review. PLoS Pathog 9(5):e1003311. https://doi.org/ 10.1371/journal.ppat.1003311

Burrack-Lange SC, Personne Y, Huber M, Winkler E, Weile J, Knabbe C, Gorig J, Rohde H (2018) Multicenter assessment of the rapid Unyvero blood culture molecular assay. J Med Microbiol 67(9):1294-1301. https://doi.org/10.1099/jmm.0.000804

Chaim W, Karpas Z, Lorber A (2003) New technology for diagnosis of bacterial vaginosis. Eur J Obstet Gynecol Reprod Biol 111(1):83-87

Chingin K, Liang J, Hang Y, Hu L, Chen H (2015) Rapid recognition of bacteremia in humans using atmospheric pressure chemical ionization mass spectrometry of volatiles emitted by blood cultures. RSC Adv 5:13952-13957. https://doi.org/10.1039/C4RA16502K

Coronel Teixeira R, Rodríguez M, Jiménez de Romero N, Bruins M, Gómez R, Yntema JB, Chaparro Abente G, Gerritsen JW, Wiegerinck W, Pérez Bejerano D, Magis-Escurra C (2017) The potential of a portable, point-of-care electronic nose to diagnose tuberculosis. J Infect 75(5):441-447. https://doi.org/10.1016/j. jinf.2017.08.003 
Costanzo M, Zacchia M, Bruno G, Crisci D, Caterino M, Ruoppolo M (2017) Integration of proteomics and metabolomics in exploring genetic and rare metabolic diseases. Kidney Dis (basel) 3(2):6677. https://doi.org/10.1159/000477493

Cumeras R, Figueras E, Davis CE, Baumbach JI, Gracia I (2015) Review on ion mobility spectrometry Part 1: current instrumentation. Analyst 140(5):1376-90. https://doi.org/10.1039/c4an0 $1100 \mathrm{~g}$

Darwiche K, Baumbach JI, Sommerwerck U, Teschler H, Freitag L (2011) Bronchoscopically obtained volatile biomarkers in lung cancer. Lung 189(6):445-452. https://doi.org/10.1007/ s00408-011-9324-1

Daulton E, Wicaksono A, Bechar J, Covington JA, Hardwicke J (2020) The detection of wound infection by ion mobility chemical analysis. Biosensors (Basel) 10(3) https://doi.org/10.3390/bios 100300 19

Drees C, Vautz W, Liedtke S, Rosin C, Althoff K, Lippmann M, Zimmermann S, Legler TJ, Yildiz D, Perl T, Kunze-Szikszay N (2019) GC-IMS headspace analyses allow early recognition of bacterial growth and rapid pathogen differentiation in standard blood cultures. Appl Microbiol Biotechnol 103(2122):9091-9101. https://doi.org/10.1007/s00253-019-10181-x

Elmassry MM, Piechulla B (2020) Volatilomes of bacterial infections in humans. Front Neurosci 14:257. https://doi.org/10.3389/fnins. 2020.00257

Eng K, Alkhouri N, Cikach F, Patel N, Yan C, Grove D, Lopez R, Rome E, Dweik RA (2015) Analysis of breath volatile organic compounds in children with chronic liver disease compared to healthy controls. J Breath Res 9(2):026002. https://doi.org/10. 1088/1752-7155/9/2/026002

Filipiak W, Beer R, Sponring A, Filipiak A, Ager C, Schiefecker A, Lanthaler S, Helbok R, Nagl M, Troppmair J, Amann A (2015) Breath analysis for in vivo detection of pathogens related to ventilator-associated pneumonia in intensive care patients: a prospective pilot study. J Breath Res 9(1):016004. https://doi.org/10.1088/ 1752-7155/9/1/016004

Fink T, Baumbach JI, Kreuer S (2014) Ion mobility spectrometry in breath research. J Breath Res 8(2):027104. https://doi.org/10. 1088/1752-7155/8/2/027104

Fowler SJ, Basanta-Sanchez M, Xu Y, Goodacre R, Dark PM (2015) Surveillance for lower airway pathogens in mechanically ventilated patients by metabolomic analysis of exhaled breath: a casecontrol study. Thorax 70(4):320-325. https://doi.org/10.1136/ thoraxjnl-2014-206273

Gao J, Zou Y, Wang Y, Wang F, Lang L, Wang P, Zhou Y, Ying K (2016) Breath analysis for noninvasively differentiating Acinetobacter baumannii ventilator-associated pneumonia from its respiratory tract colonization of ventilated patients. J Breath Res 10(2):027102. https://doi.org/10.1088/1752-7155/10/2/027102

Garner CE, Smith S, Bardhan PK, Ratcliffe NM, Probert CS (2009) A pilot study of faecal volatile organic compounds in faeces from cholera patients in Bangladesh to determine their utility in disease diagnosis. Trans R Soc Trop Med Hyg 103(11):1171-1173. https://doi.org/10.1016/j.trstmh.2009.02.004

Gilchrist FJ, Bright-Thomas RJ, Jones AM, Smith D, Spaněl P, Webb AK, Lenney W (2013) Hydrogen cyanide concentrations in the breath of adult cystic fibrosis patients with and without Pseudomonas aeruginosa infection. J Breath Res 7(2):026010. https:// doi.org/10.1088/1752-7155/7/2/026010

Goeminne PC, Vandendriessche T, Van Eldere J, Nicolai BM, Hertog ML, Dupont LJ (2012) Detection of Pseudomonas aeruginosa in sputum headspace through volatile organic compound analysis. Respir Res 13(1):87. https://doi.org/10.1186/1465-9921-13-87

Khatua S, Geltemeyer AM, Gourishankar A (2017) Tuberculosis: is the landscape changing? Pediatr Res 81(1-2):265-270. https:// doi.org/10.1038/pr.2016.205
Kramer R, Sauer-Heilborn A, Welte T, Guzman CA, Höfle MG, Abraham WR (2015) A rapid method for breath analysis in cystic fibrosis patients. Eur J Clin Microbiol Infect Dis 34(4):745-751. https://doi. org/10.1007/s10096-014-2286-5

Kumar A, Ellis P, Arabi Y, Roberts D, Light B, Parrillo JE, Dodek P, Wood G, Kumar A, Simon D, Peters C, Ahsan M, Chateau D (2009) Initiation of inappropriate antimicrobial therapy results in a fivefold reduction of survival in human septic shock. Chest 136(5):1237-1248. https://doi.org/10.1378/chest.09-0087

Kunze N, Weigel C, Vautz W, Schwerdtfeger K, Junger M, Quintel M, Perl T (2015) Multi-capillary column-ion mobility spectrometry (MCC-IMS) as a new method for the quantification of occupational exposure to sevoflurane in anaesthesia workplaces: an observational feasibility study. J Occup Med Toxicol 10:12. https://doi.org/10.1186/s12995-015-0056-7

Kviatkovski I, Shushan S, Oron Y, Frumin I, Amir D, Secundo L, Livne E, Weissbrod A, Sobel N, Helman Y (2018) Smelling Pseudomonas aeruginosa infections using a whole-cell biosensor - an alternative for the gold-standard culturing assay. J Biotechnol 267:45-49. https://doi.org/10.1016/j.jbiotec.2017.12.023

Lacey L, Daulton E, Wicaksono A, Covington JA, Quenby S (2020) Detection of group B Streptococcus in pregnancy by vaginal volatile organic compound analysis: a prospective exploratory study. Transl Res 216:23-29. https://doi.org/10.1016/j.trsl.2019.09.002

Lechner M, Karlseder A, Niederseer D, Lirk P, Neher A, Rieder J, Tilg $\mathrm{H}$ (2005) $H$. pylori infection increases levels of exhaled nitrate. Helicobacter 10(5):385-90. https://doi.org/10.1111/j.1523-5378. 2005.00345.x

Liebeke M, Dorries K, Meyer H, Lalk M (2012) Metabolome analysis of gram-positive bacteria such as Staphylococcus aureus by GC-MS and LC-MS. Methods Mol Biol 815:377-398. https://doi. org/10.1007/978-1-61779-424-7_28

MacFadden DR, Leis JA, Mubareka S, Daneman N (2014) The opening and closing of empiric windows: the impact of rapid microbiologic diagnostics. Clin Infect Dis 59(8):1199-1200. https://doi. org/10.1093/cid/ciu493

Nakayama Y, Graham DY (2004) Helicobacter pylori infection: diagnosis and treatment. Expert Rev Anti Infect Ther 2(4):599-610. https://doi.org/10.1586/14787210.2.4.599

Nakhleh MK, Jeries R, Gharra A, Binder A, Broza YY, Pascoe M, Dheda K, Haick H (2014) Detecting active pulmonary tuberculosis with a breath test using nanomaterial-based sensors. Eur Respir J 43(5):1522-1525. https://doi.org/10.1183/09031936.00019114

Nasir M, Bean HD, Smolinska A, Rees CA, Zemanick ET, Hill JE (2018) Volatile molecules from bronchoalveolar lavage fluid can "rule-in" Pseudomonas aeruginosa and "rule-out" Staphylococcus aureus infections in cystic fibrosis patients. Sci Rep 8(1):826. https://doi.org/10.1038/s41598-017-18491-8

Neerincx AH, Geurts BP, van Loon J, Tiemes V, Jansen JJ, Harren FJ, Kluijtmans LA, Merkus PJ, Cristescu SM, Buydens LM, Wevers RA (2016) Detection of Staphylococcus aureus in cystic fibrosis patients using breath VOC profiles. J Breath Res 10(4):046014. https://doi.org/10.1088/1752-7155/10/4/046014

O'Hara M, Mayhew CA (2009) A preliminary comparison of volatile organic compounds in the headspace of cultures of Staphylococcus aureus grown in nutrient, dextrose and brain heart bovine broths measured using a proton transfer reaction mass spectrometer. J Breath Res 3(2):027001. https://doi.org/10.1088/17527155/3/2/027001

Pancholi P, Carroll KC, Buchan BW, Chan RC, Dhiman N, Ford B, Granato PA, Harrington AT, Hernandez DR, Humphries RM, Jindra MR, Ledeboer NA, Miller SA, Mochon AB, Morgan MA, Patel R, Schreckenberger PC, Stamper PD, Simner PJ, Tucci NE, Zimmerman C, Wolk DM (2018) Multicenter evaluation of the accelerate phenotest $\mathrm{BC}$ kit for rapid identification and phenotypic antimicrobial susceptibility testing using morphokinetic cellular 
analysis. J Clin Microbiol 56(4) https://doi.org/10.1128/JCM. 01329-17

Patel M, Fowler D, Sizer J, Walton C (2019) Faecal volatile biomarkers of Clostridium difficile infection. PLoS ONE 14(4):e0215256. https://doi.org/10.1371/journal.pone.0215256

Paul M, Shani V, Muchtar E, Kariv G, Robenshtok E, Leibovici L (2010) Systematic review and meta-analysis of the efficacy of appropriate empiric antibiotic therapy for sepsis. Antimicrob Agents Chemother 54(11):4851-4863. https://doi.org/10.1128/ AAC.00627-10

Purkhart R, Kohler H, Liebler-Tenorio E, Meyer M, Becher G, Kikowatz A, Reinhold P (2011) Chronic intestinal Mycobacteria infection: discrimination via VOC analysis in exhaled breath and headspace of feces using differential ion mobility spectrometry. J Breath Res 5(2):027103. https://doi.org/10.1088/1752-7155/5/ $2 / 027103$

Ratiu IA, Ligor T, Bocos-Bintintan V, Buszewski B (2017) Mass spectrometric techniques for the analysis of volatile organic compounds emitted from bacteria. Bioanalysis 9(14):1069-1092. https://doi.org/10.4155/bio-2017-0051

Ratiu IA, Ligor T, Bocos-Bintintan V, Szeliga J, Machala K, Jackowski M, Buszewski B (2019) GC-MS application in determination of volatile profiles emitted by infected and uninfected human tissue. J Breath Res 13(2):026003. https://doi.org/10.1088/1752-7163/ aaf708

Rodriguez-Sanchez B, Sanchez-Carrillo C, Ruiz A, Marin M, Cercenado E, Rodriguez-Creixems M, Bouza E (2014) Direct identification of pathogens from positive blood cultures using matrix-assisted laser desorption-ionization time-of-flight mass spectrometry. Clin Microbiol Infect 20(7):O421-O427. https:// doi.org/10.1111/1469-0691.12455

Roine A, Saviauk T, Kumpulainen P, Karjalainen M, Tuokko A, Aittoniemi J, Vuento R, Lekkala J, Lehtimaki T, Tammela TL, Oksala NK (2014) Rapid and accurate detection of urinary pathogens by mobile IMS-based electronic nose: a proof-of-principle study. PLoS ONE 9(12):e114279. https://doi.org/10.1371/journ al.pone.0114279

Ruszkiewicz DM, Sanders D, O'Brien R, Hempel F, Reed MJ, Riepe AC, Bailie K, Brodrick E, Darnley K, Ellerkmann R, Mueller O, Skarysz A, Truss M, Wortelmann T, Yordanov S, Thomas CLP, Schaaf B, Eddleston M (2020) Diagnosis of COVID-19 by analysis of breath with gas chromatography-ion mobility spectrometry - a feasibility study. EClinicalMedicine 29:100609. https://doi. org/10.1016/j.eclinm.2020.100609

Sahota AS, Gowda R, Arasaradnam RP, Daulton E, Savage RS, Skinner JR, Adams E, Ward SA, Covington JA (2016) A simple breath test for tuberculosis using ion mobility: a pilot study. Tuberculosis (edinb) 99:143-146. https://doi.org/10.1016/j.tube.2016.05.005

Schnabel R, Fijten R, Smolinska A, Dallinga J, Boumans ML, Stobberingh E, Boots A, Roekaerts P, Bergmans D, van Schooten FJ (2015) Analysis of volatile organic compounds in exhaled breath to diagnose ventilator-associated pneumonia. Sci Rep 5:17179. https://doi.org/10.1038/srep17179

Schulz S, Dickschat JS (2007) Bacterial volatiles: the smell of small organisms. Nat Prod Rep 24(4):814-842. https://doi.org/10.1039/ b507392h

SepNet Critical Care Trials Group (2016) Incidence of severe sepsis and septic shock in German intensive care units: the prospective, multicentre INSEP study. Intensive Care Med 42(12):1980-1989. https://doi.org/10.1007/s00134-016-4504-3

Singer M, Deutschman CS, Seymour CW, Shankar-Hari M, Annane D, Bauer M, Bellomo R, Bernard GR, Chiche JD, Coopersmith CM, Hotchkiss RS, Levy MM, Marshall JC, Martin GS, Opal SM, Rubenfeld GD, van der Poll T, Vincent JL, Angus DC (2016) The third international consensus definitions for sepsis and septic shock (sepsis-3). JAMA 315(8):801-810. https://doi.org/10.1001/ jama.2016.0287

Slingers G, Vanden Eede M, Lindekens J, Spruyt M, Goelen E, Raes M, Koppen G (2021) Real-time versus thermal desorption selected ion flow tube mass spectrometry for quantification of breath volatiles. Rapid Commun Mass Spectrom 35(4):e8994. https://doi.org/ $10.1002 / \mathrm{rcm} .8994$

Speckbacher V, Zeilinger S, Zimmermann S, Mayhew CA, Wiesenhofer H, Ruzsanyi V (2021) Monitoring the volatile language of fungi using gas chromatography-ion mobility spectrometry. Anal Bioanal Chem. https://doi.org/10.1007/s00216-021-03242-6

Stevenson M, Pandor A, Martyn-St James M, Rafia R, Uttley L, Stevens J, Sanderson J, Wong R, Perkins GD, McMullan R, Dark P (2016) Sepsis: the LightCycler SeptiFast Test MGRADE(R), SepsiTest and IRIDICA BAC BSI assay for rapidly identifying bloodstream bacteria and fungi - a systematic review and economic evaluation. Health Technol Assess 20(46):1-246. https://doi.org/10.3310/hta20460

Storer MK, Hibbard-Melles K, Davis B, Scotter J (2011) Detection of volatile compounds produced by microbial growth in urine by selected ion flow tube mass spectrometry (SIFT-MS). J Microbiol Methods 87(1):111-113. https://doi.org/10.1016/j.mimet.2011.06. 012

Tabak YP, Vankeepuram L, Ye G, Jeffers K, Gupta V, Murray PR (2018) Blood culture turnaround time in U.S. Acute care hospitals and implications for laboratory process optimization. J Clin Microbiol 56(12) https://doi.org/10.1128/JCM.00500-18

Tait E, Perry JD, Stanforth SP, Dean JR (2014) Bacteria detection based on the evolution of enzyme-generated volatile organic compounds: determination of Listeria monocytogenes in milk samples. Anal Chim Acta 848:80-87. https://doi.org/10.1016/j.aca.2014. 07.029

Tumbarello M, Spanu T, Di Bidino R, Marchetti M, Ruggeri M, Trecarichi EM, De Pascale G, Proli EM, Cauda R, Cicchetti A, Fadda G (2010) Costs of bloodstream infections caused by Escherichia coli and influence of extended-spectrum-betalactamase production and inadequate initial antibiotic therapy. Antimicrob Agents Chemother 54(10):4085-4091. https://doi. org/10.1128/AAC.00143-10

Umber BJ, Shin HW, Meinardi S, Leu SY, Zaldivar F, Cooper DM, Blake DR (2013) Gas signatures from Escherichia coli and Escherichia coli-inoculated human whole blood. Clin Transl Med 2:13. https://doi.org/10.1186/2001-1326-2-13

van Oort PM, de Bruin S, Weda H, Knobel HH, Schultz MJ, Bos LD, On Behalf Of The Mars C (2017) Exhaled breath metabolomics for the diagnosis of pneumonia in intubated and mechanicallyventilated intensive care unit (ICU)-patients. Int J Mol Sci 18(2) https://doi.org/10.3390/ijms18020449

Warhurst G, Dunn G, Chadwick P, Blackwood B, McAuley D, Perkins GD, McMullan R, Gates S, Bentley A, Young D, Carlson GL, Dark P (2015) Rapid detection of health-care-associated bloodstream infection in critical care using multipathogen real-time polymerase chain reaction technology: a diagnostic accuracy study and systematic review. Health Technol Assess 19(35):1-142. https://doi.org/10.3310/hta19350

Wilson AD (2020) Noninvasive early disease diagnosis by electronicnose and related VOC-detection devices. Biosensors (Basel) 10(7) https://doi.org/10.3390/bios10070073

Woolfenden E (2010) Sorbent-based sampling methods for volatile and semi-volatile organic compounds in air Part 1: Sorbent-based air monitoring options. J Chromatogr A 1217(16):2674-2684. https:// doi.org/10.1016/j.chroma.2009.12.042

Zetola NM, Modongo C, Matsiri O, Tamuhla T, Mbongwe B, Matlhagela K, Sepako E, Catini A, Sirugo G, Martinelli E, Paolesse R, Di Natale C (2017) Diagnosis of pulmonary tuberculosis and 
assessment of treatment response through analyses of volatile compound patterns in exhaled breath samples. J Infect 74(4):367376. https://doi.org/10.1016/j.jinf.2016.12.006

Zhong Q, Cheng F, Liang J, Wang X, Chen Y, Fang X, Hu L, Hang Y (2019) Profiles of volatile indole emitted by Escherichia coli based on CDI-MS. Sci Rep 9(1):13139. https://doi.org/10.1038/ s41598-019-49436-y
Zoller HF, Clark WM (1921) The production of volatile fatty acids by bacteria of the dysentery group. J Gen Physiol 3(3):325-330

Publisher's note Springer Nature remains neutral with regard to jurisdictional claims in published maps and institutional affiliations. 